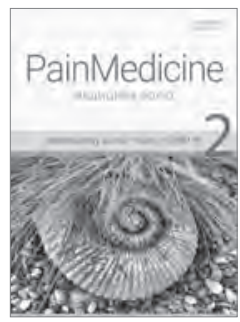

\title{
Досвід застосування галоаерозольтерапії в реабілітації хворих на бронхіальну астму
}

\author{
Косовєров Є. О., Степанова В. С., Новікова А. І. \\ ДУ «Український науково-дослідний інститут медичної реабілітації та курортології МОЗ України, \\ м. Одеса, Україна
}

Актуальність. Методи медикаментозної терапії захворювань органів дихання чітко регламентовані міжнародними і національними протоколами. Проте розробка нових та оптимізація вже відомих методів реабілітації із застосуванням немедикаментозних методів дуже актуальна, особливо для пацієнтів 3 алергічними захворюваннями.

Мета дослідження: обгрунтування доцільності призначення галоаерозольтерапії (ГАТ) хворим на бронхіальну астму (БА).

Матеріали та методи дослідження. В основу роботи покладено аналіз клінічних спостережень за 46 пацієнтами віком від 14 до 50 років із БА, що проходили курс ГАТ. Курс складався 3 15-20 щоденних сеансів тривалістю 20-60 хв. Нами було проаналізовано результати 46 тестів контролю над астмою (ACQ-5). Тестування проводили дворазово, перед лікуванням та через рік після завершення лікування.

Результати дослідження та їх обговорення. Середній результат тесту ACQ-5 складав на початку лікування $1,36 \pm 0,11$ балів, наприкінці лікування $-0,96 \pm 0,06$ балів $(\mathrm{p}<0,001)$. Дослідження показало значну ефективність застосування ГАТ у 75 \% випадків у вигляді повного контролю над астмою $(0,62 \pm 0,04$ балів). У $21 \%$ хворих отримано задовільну ефективність перебігу захворювання $(0,83 \pm 0,07$ балів). Близько $3 \%$ $(1,26 \pm 0,1$ балів) пацієнтів мали несуттєвий ефект. Впровадження методу галоаерозольтерапії $€$ актуальним для реабілітації в амбулаторних умовах, особливо для пацієнтів, які не мають можливості отримати санаторнокурортне лікування.

Висновки. Застосування опанованих на базі поліклініки реабілітаційних комплексів з ГАТ при лікуванні пацієнтів із БА та алергічними захворюваннями оптимізує методологію надання медичної допомоги хворим вказаної нозологічної групи.

Перспективи подальших досліджень. Планується проведення досліджень, спрямованих на вивчення можливостей для диференційованого призначення методу, з урахуванням ступеня тяжкості захворювання та коморбідної патології.

Ключові слова: реабілітація, галоаерозольтерапія, бронхіальна астма.

Конфлікт інтересів немає. 